International Research Journal of Management, IT \& Social Sciences
Available online at https://sloap.org/journals/index.php/irjmis/
Vol. 6 No. 3, May 2019, pages: $37 \sim 45$
ISSN: 2395-7492
https://doi.org/10.21744/irjmis.v6n3.627

\title{
The Role of Business Strategies, Environmental Uncertainty and Decentralization as Moderating the Effect of Management Accounting Systems on Managerial Performance
}

\author{
Ni Ketut Ayuk Kesumawati a \\ I.G.A. Made Asri Dwija Putri ${ }^{\text {b }}$
}

A.A.N.B. Dwirandra ${ }^{c}$

Article history:

Received: 27 December 2018

Accepted: 31 March 2019

Published: 24 April 2019

\section{Keywords:}

business strategy;

decentralization;

environmental uncertainty;

management accounting system;

managerial performance;

\begin{abstract}
The data of this research is primary data and data collection is done through a questionnaire. While the data analysis used include classical assumption test, linear regression analysis, and partial test. Based on the results of the research can be seen that (1) Management accounting system significant effect on managerial performance This means that with the application of an adequate accounting system will improve managerial performance in Travel Agent Services Company in Bali, (2) Business strategy moderate the influence of management accounting system on managerial performance, This means that the use of appropriate business strategies tend to be prospective, will play a role in strengthening the influence of the application of management accounting system to the managerial performance of Travel Agent Services Company in Bali, (3) Environmental uncertainty moderate the influence of management accounting system on managerial performance, meaning that environmental uncertainty will strengthen the influence implementation of management accounting system to managerial performance of Travel Agent Services Company in Bali, (4) Decentralization moderate the influence of management accounting system on managerial performance, It means that decentralization can strengthen the influence of application of system management accounting on managerial performance of Travel Agent Services Company in Bali.
\end{abstract}

2395-7492@ Copyright 2019. The Author. This is an open-access article under the CC BY-SA license (https://creativecommons.org/licenses/by-sa/4.0/) All rights reserved.

\section{Author correspondence:}

Ni Ketut Ayuk Kesumawati,

Faculty of Economic and Business Udayana University, Bali, Indonesia.

Email address: ayukkesuma@gmail.com

\footnotetext{
${ }^{a}$ Faculty of Economic and Business, Udayana University, Bali, Indonesia

${ }^{\mathrm{b}}$ Faculty of Economic and Business, Udayana University, Bali, Indonesia

${ }^{\mathrm{c}}$ Faculty of Economic and Business, Udayana University, Bali, Indonesia
} 


\section{Introduction}

Management information as one of the products of management accounting systems has a role in predicting the consequences of various alternative actions that can be carried out in various activities such as planning, supervision and decision making. According to Chenhall \& Morris (1986), the characteristics of management accounting information that is useful based on managerial perceptions as decision making are categorized in four traits, namely scope, timeliness, aggregation, integration. Scope is related to the provision of information that focuses on internal and external companies, timeliness is related to the speed of reporting, aggregation provides a summary of information in accordance with functional areas, time periods or through decision models, and integration consists of information about the activities of other departments in the company and how decisions are made in one department affects performance in other departments (Dewi et al., 2018).

Several previous studies showed different research results. Solechan (2009); Yuristisia (2011); Meiranto (2013); Nopalia (2012); Erna (2006); Tjhai Fung Jen (2002), managed to prove that management accounting systems have a significant and positive effect on managerial performance. However, research conducted by Rustiana (2002), shows that management accounting information systems have no effect on managerial performance. Likewise, the research of Ferona (2013) and Sigilipu (2013), has not succeeded in proving the existence of a significant influence between management accounting systems on managerial performance.

The findings that indicate the inconsistency between one study and another, indicate the possibility of other variables that influence the relationship between management accounting systems and managerial performance. According to Ghozali (2002), it may be caused by certain factors (situational factors) or better known as contingency variables. The contingency variables in this study are a business strategy (Yuristisia, 2011), environmental uncertainty (Erna, 2006) and decentralization (Solechan, 2009), so research is needed on contingency approaches. Control systems including management accounting systems and contingency approaches allow for other variables that act as intervening variables or moderating variables.

The management accounting system is not only applied to manufacturing and trading companies but also applies to service companies. Service companies are business units whose activities produce products that are intangible (services) with the intention of gaining profits (Mulya, 2013). Travel Agent is one of the service companies that develop continuously through information relating to the world of travel in general and travel in particular, which makes consumers more easily get services (Swastika, 2013).

In a travel agent, to win the competition that occurs in the national market and the global market today, the travel agent business must be able to provide satisfaction to its customers, and this can be done by providing good quality services, fast and appropriate services, and costs relatively competitive costs. In addition, information is very important to support the continuity of the development of travel agents, but the information systems that are owned often cannot work properly. One of the cases that occurred in a travel agent such as the First Travel case, where fraud was committed to customers who were going to perform Umrah. In addition to these examples of cases in travel agents, things that often happen are sudden price changes by suppliers, cancellation of bookings by the customer, and payments that are not timed to become a problem that is often experienced that makes managers must be quick in making a decision.

Business strategy is one variable that can be considered in the relationship between management accounting systems and managerial performance. Business strategy is a comprehensive and integrated unity of corporate plans needed to achieve company goals (Supriyono, 2001). Business strategy is also a pattern of certain decisions and actions that allow managers to achieve organizational goals (Kartikawati, 2005). Management requires a business strategy as a tool to win the competition and maintain the survival of the company. The company sometimes changes business strategies that have been implemented to adapt to its industrial environment. Business strategies in a travel agent such as how to provide services to customers by giving discounts or promos at certain times, where it can attract customers.

Miles \& Snow (2010), describe four (4) types of business strategies that focus on the level of product changes and markets including defender, prospector, analyzer, and reactor. The defender has a tendency to not (very little) carry out product and market development. Instead, prospectors are constantly looking for market opportunities and become creators of change. The analyzer combines the characters possessed by a defender or prospector. While the reactor is a category where top management often faces change and uncertainty in its organizational environment but is unable to respond effectively. With the existence of business strategies implemented the company is expected to be able to improve managerial performance.

Environmental uncertainty is often a factor that causes organizations to make adjustments to the environment. According to Gordon \& Narayanan (1984), environmental uncertainty is a manager's perception of factors outside the company such as the industrial environment, technology, competition, and the customer environment. Environmental 
uncertainty will make it difficult for managers to plan and control the company's operations. The condition of environmental uncertainty can be reduced by using a management accounting system because one of the characteristics of a management accounting system is an important source of information that helps management control its activities and reduces the problem of environmental uncertainty in order to achieve company goals (Gordon \& Miller, 1976). Environmental uncertainty that is often experienced by a travel agent such as natural disasters, price increases and rate increases that can reduce customer interest in doing tours.

Decentralization is the next moderating variable in this study assuming the level of decentralization will affect the level of need for the characteristics of management accounting information (Solechan, 2009). Decentralization is the delegation of responsibility authority to managers lower in the organization to provide a broad field of power or wisdom for company activities (Solechan, 2009). This decentralization may only occur as a result of a response to environmental or technological conditions in a special organizational subunit. Thus, decentralization is needed to anticipate an increasingly complex environment and full of uncertainty. So the impact of the interaction between management accounting systems and decentralization will be more positive towards managerial performance. Conformity between information and the needs of decision makers will support the quality of decisions that will be taken and ultimately can improve company performance. Decentralization in travel agents in terms of how decisions are made when developing new services, upgrading or terminating employment, selecting and evaluating investments, allocating budgets and determining selling prices.

\section{Literature Review}

According to Chia (1994), the management accounting system is an organizational control mechanism and an effective tool for presenting information and is useful in predicting the possible consequences of various activities. And the management accounting system as a producer of information used in the organization's control mechanism to be based on the basis of policymaking. Yuristisia (2011), shows the management accounting system significantly on managerial performance. The results of this study are also in line with other studies that also show the same results, namely research conducted by Nopalia (2012), the results of his research indicate that the use of management accounting systems simultaneously influences managerial performance. The characteristics of the information available in the organization will be effective if it can support information users or decision makers. Based on the results of research conducted by several researchers above, it can be hypothesized:

H1: Management accounting systems affect managerial performance.

Managerial performance is influenced by interactions between management accounting systems and business strategies (Yuristisia, 2011). Business strategy is a moderating variable in this study, the moderating variable is a variable that has a strong influence of dependence on the relationship of dependent variables and independent variables that can change the initial relationship between independent and bound variables (Now, 1992). Faisal (2006), study shows that business strategies affect performance, where the existence of a strategy will support the company in improving its performance. From the description, the hypothesis proposed is as follows:

$\mathrm{H} 2$ : Business strategies moderate (strengthen or weaken) the effect of management accounting systems on managerial performance.

Managerial performance is influenced by interactions between management accounting systems and environmental uncertainties. So, the higher the level of environmental uncertainty faced by a company, the higher the usefulness of management accounting systems is expected to improve managerial performance (Yuristisia, 2011). From the description, the hypothesis proposed is as follows:

H3: Environmental uncertainty moderates (strengthens or weakens) the effect of management accounting systems on managerial performance.

Managerial performance is influenced by the interaction between management accounting systems and decentralization. Decentralization variables as moderating variables that influence the relationship between management accounting system variables with managerial performance variables. Yuristisia (2011), shows that decentralization functions as a moderator variable and supports that the management accounting system will have a positive effect on managerial performance for companies at a high level of decentralization compared to low levels of decentralization. From the description, the hypothesis proposed is as follows:

H4: Decentralization moderates (strengthens or weakens) the effect of management accounting systems on managerial performance.

Kesumawati, N. K. A., Putri, I. M. A. D., \& Dwirandra, A. (2019). The role of business strategies, environmental uncertainty and decentralization as moderating the effect of management accounting systems on managerial performance. International Research Journal of Management, IT and Social Sciences, 6(3), 37-45. 


\section{Materials and Methods}

The location of this research was conducted on Travel Agent service companies in Bali. The reasons for location selection are based on several considerations, namely to prove whether there is indeed an influence of business strategy, environmental uncertainty, and decentralization on managerial performance. Travel Agent is one of the fastest growing service companies in Bali and easy to run.

In this study, there were 375 Travel Agent service companies in Bali that were registered as ASITA (Association of Indonesian Tours and Travel Agencies). The sample in this study is the manager of the Travel Agent Company because the highest decision making is in the manager. In this study, determining the number of samples using the proportionate stratified random sampling technique, which is sampling from members of the population in a random and proportionate manner (Sugiyono, 2009). The population in this study was 375, the sample of this study was determined by the Slovin calculation formula by region, namely Denpasar, Badung and Other Cities (Outside Denpasar and Badung). From the population $(\mathrm{N})$ there are a number of research samples (n) that must be taken based on Slovin formula with a confidence level of $95 \%(\mathrm{a}=0.05)$ as follows:

$$
\begin{aligned}
& \mathrm{n}=\frac{\mathrm{N}}{\mathrm{N}(a)^{2}+1} \\
& \mathrm{n}=\frac{375}{375(0,05)^{2}+1} \\
& \mathrm{n}=193
\end{aligned}
$$

193 respondents included 116 travel agents in the Denpasar area, 72 travel agents from the Badung region, 4 travel agents from the Gianyar region and 1 travel agent from the Tabanan region.

The data collection method used is a survey method in the form of a questionnaire. The hypothesis testing of this study was conducted using the moderated regression analysis (MRA) model with interaction tests.

\section{Results and Discussions}

Testing the ability of business strategies to moderate the influence of management accounting systems on managerial performance

Table 1

\begin{tabular}{|c|c|c|c|c|c|c|}
\hline \multirow[b]{2}{*}{ Model } & & \multicolumn{2}{|c|}{ Unstandardized Coefficients } & \multirow{2}{*}{$\begin{array}{c}\text { Standardized } \\
\text { Coefficients } \\
\text { Beta }\end{array}$} & \multirow[b]{2}{*}{$\mathrm{t}$} & \multirow[b]{2}{*}{ Sig. } \\
\hline & & B & Std. Error & & & \\
\hline \multirow[t]{4}{*}{1} & (Constant) & -7.758 & 3.072 & & -2.526 & .013 \\
\hline & $\begin{array}{l}\text { Management of Accounting } \\
\text { System (X1) }\end{array}$ & .753 & .138 & 1.330 & 5.452 & .000 \\
\hline & Business Strategy (X2) & .954 & .082 & 1.275 & 11.677 & .000 \\
\hline & $\begin{array}{l}\text { Moderation of Business } \\
\text { Strategy }(\mathrm{X} 1 \mathrm{X} 2)\end{array}$ & -.017 & .003 & -1.638 & -5.819 & .000 \\
\hline
\end{tabular}

Calculation Results of Moderated Regression Analysis (MRA)

Management of Accounting System and Business Strategy

Primary Data, 2018

The significance value or $\mathrm{P}$ value in the management accounting system variable (X1) is 0,000 which means it is less than the significance level of $5 \%$ or 0.05 , this means that the management accounting system (X1) has an effect on managerial performance $(\mathrm{Y})$.

The significance value or P-value in business strategy (X2) is 0,000 which means it is less than the significance level of $5 \%$ or 0.05 , this means that the higher the level of business strategy (X2) will increase the influence of management accounting system (X1) on managerial performance $(\mathrm{Y})$. 
The significance value of the interaction between the moderating variable of the management accounting system (X1) and business strategy (X2) is 0,000 which means that it is less than the significance level of 5\% or 0.05 , this means that the business strategy has a significant effect on the increase in the influence of the system management accounting (X1) on managerial performance (Y).

Testing the ability of environmental uncertainty to moderate the influence of management accounting systems on managerial performance

Table 2

Calculation Results of Moderated Regression Analysis (MRA)

Management of Accounting Systems and Environmental Uncertainty

\begin{tabular}{|c|c|c|c|c|c|c|}
\hline \multirow[b]{2}{*}{ Model } & & \multicolumn{2}{|c|}{ Unstandardized Coefficients } & \multirow{2}{*}{$\begin{array}{c}\text { Standardized } \\
\text { Coefficients } \\
\text { Beta }\end{array}$} & \multirow[b]{2}{*}{$\mathrm{t}$} & \multirow[b]{2}{*}{ Sig. } \\
\hline & & $\mathrm{B}$ & Std. Error & & & \\
\hline \multirow[t]{4}{*}{1} & (Constant) & 21.815 & 2.234 & & 9.763 & .000 \\
\hline & $\begin{array}{l}\text { Management of Accounting Systems } \\
\text { (X1) }\end{array}$ & -.300 & .085 & -.530 & -3.536 & .001 \\
\hline & Environmental Uncertainty (X3) & .185 & .062 & .245 & 2.959 & .004 \\
\hline & $\begin{array}{l}\text { Moderation of Environmental } \\
\text { Uncertainty (X1X3) }\end{array}$ & .014 & .002 & 1.265 & 5.796 & .000 \\
\hline
\end{tabular}

Primary Data, 2018

The significance value or $\mathrm{P}$ value in the management accounting system variable (X1) is 0.001 which means it is less than the significance level of $5 \%$ or 0.05 , this means that the management accounting system (X1) has an effect on managerial performance $(\mathrm{Y})$.

Significance value or P-value on environmental uncertainty (X3) of 0.004 which means less than the significance level of $5 \%$ or 0.05 , this means that the higher the level of environmental uncertainty (X3) will increase the influence of management accounting system (X1) on managerial performance ( Y).

The significance value of the interaction of the moderating management accounting system variable (X1) with environmental uncertainty (X3) is 0,000 which means that it is less than the significance level of $5 \%$ or 0.05 , this means that the moderating variable has a significant impact on the increase in the system's influence management accounting (X1) on managerial performance (Y).

Testing the ability of decentralization moderates the effect of management accounting systems on managerial performance

Table 3

Calculation Results of Moderated Regression Analysis (MRA) Management of Accounting Systems and Decentralization

\begin{tabular}{|c|c|c|c|c|c|c|}
\hline & & \multicolumn{2}{|c|}{ Unstandardized Coefficients } & \multirow{2}{*}{$\begin{array}{c}\text { Standardized } \\
\text { Coefficients } \\
\text { Beta } \\
\end{array}$} & \multirow[b]{2}{*}{$\mathrm{t}$} & \multirow[b]{2}{*}{ Sig. } \\
\hline & & B & Std. Error & & & \\
\hline \multirow[t]{4}{*}{1} & (Constant) & 4.877 & 2.909 & & 1.676 & .010 \\
\hline & Management of Accounting Systems & .317 & .100 & .559 & 3.172 & .002 \\
\hline & Decentralization & .833 & .149 & .654 & 5.590 & .000 \\
\hline & Moderation of Decentralization & -.003 & .005 & -.197 & -.715 & .005 \\
\hline
\end{tabular}

Primary Data, 2018

Kesumawati, N. K. A., Putri, I. M. A. D., \& Dwirandra, A. (2019). The role of business strategies, environmental uncertainty and decentralization as moderating the effect of management accounting systems on managerial performance. International Research Journal of Management, IT and Social Sciences, 6(3), 37-45. https://doi.org/10.21744/irjmis.v6n3.627 
The significance value or $\mathrm{P}$ value in the management accounting system variable (X1) is 0.002 which means it is smaller than the significance level of $5 \%$ or 0.05 , this means that the management accounting system (X1) has an effect on managerial performance $(\mathrm{Y})$.

The significance value or P-value in decentralization (X4) is 0,000 which means it is smaller than the significance level of $5 \%$ or 0.05 , this means that the higher the level of decentralization (X4) will increase the influence of management accounting system (X1) on managerial performance (Y).

The significance value of the interaction of the management accounting system moderation variable (X1) with decentralization (X4) is 0.005 which means it is smaller than the significance level of $5 \%$ or 0.05 , this means that the moderating variable has a significant impact on the increase in the influence of the management accounting system (X1) on managerial performance (Y).

\subsection{The Effect of management accounting systems on managerial performance}

Based on the results of the analysis it is known that the management accounting system has a significant effect on managerial performance. The results of this study support the research conducted by Yuristisia (2011) which concluded that the management accounting system had an effect on managerial performance. Yuristisia (2011) stated that with an adequate management accounting system in the organization it would improve managerial performance. The management accounting system is an important source of information to help managers control their activities and reduce uncertainty in order to achieve goals, where the role of the management accounting system itself is to predict the consequences of various actions that can be carried out in various activities from planning to decision making. This Yuristisia (2011) study concludes that the management accounting system influences managerial performance.

\subsection{The role of business strategies to moderate the influence of management accounting systems on managerial performance}

Based on the results of the analysis it is known that business strategies increase the influence of management accounting systems on managerial performance. Based on this, it can be concluded that business strategies that tend to prospectors can strengthen the influence of the management accounting system on managerial performance. Business strategy is a comprehensive and integrated unity of company plans needed to achieve company goals. The business strategy is type prospector, where companies are constantly looking for opportunities and market development and experimenting with potential responses to environmental trends that arise so that competitors must always respond (Miles and Snow, 2010).

\subsection{The role of environmental uncertainty to moderate the influence of management accounting systems on managerial performance}

Based on the results of the analysis it is known that environmental uncertainty strengthens the influence of the management accounting system on managerial performance. Environmental uncertainty can be explained where a person experiences uncertainty because he feels he does not have enough information to accurately predict the future. This uncertainty will make a leader/manager difficult in making planning and decision making. With a high level of environmental uncertainty, the higher the function of the management accounting system in improving managerial performance in travel agent companies in Bali. The results of this study are in line with Yuristisia (2011), research where environmental uncertainty moderates the effect of management accounting systems on managerial performance. In this case the role of management accounting systems such as helping management control its activities in order to achieve company goals. So that with a high level of environmental uncertainty resulting in the role of management accounting systems that increasingly influence managerial performance.

\subsection{Decentralization capabilities moderate the influence of management accounting systems on managerial performance}

Decentralization is the delegation of authority responsibilities to lower managers in the organization. Decentralization is needed to anticipate an increasingly complex environment and full of uncertainty. So that the impact of the management accounting system with managerial performance will be more positive with decentralization. The results of this study are in line with the research conducted by Yuristisia (2011), which shows decentralization as a 
moderator and reinforces that the management accounting system will affect the performance of the company at a high level of decentralization. In this study decentralization also moderates the effect of management accounting systems on managerial performance of travel agents in Bali, this shows that by giving authority to strengthen the influence of the implementation of management accounting systems on financial performance because the level of decentralization is the right form to deal with uncertainty and thus achieves performance better.

\section{Conclusion}

Descriptive analysis shows that Management Accounting System variables are included in the classification of available management accounting information systems, so it is recommended to be improved by paying attention to various information including monthly, quarterly, annual and other predictions and comparable so that companies can plan ahead with more well. The results of the descriptive analysis show that the Business Strategy variables included in the classification agree (tend to Prospector), so it is recommended to be improved by paying attention to the scope of activities, although in limited space because there are opportunities or opportunities to maximize the effort.

The results of the descriptive analysis show that the Environmental Uncertainty variables included in the classification are acceptable, so it is recommended to be improved by paying attention to the market activities of competitors at least in the last 5 years, in order to be able to know the development of the business that is happening. The results of the descriptive analysis show that the Decentralization variable is included in the classification approaching full delegation, so it is suggested to be further improved by paying attention to how large investments are chosen, thus minimizing the occurrence of errors in determining investment.

Further research is expected to be able to examine more deeply not limited to management accounting system variables, business strategy, environmental uncertainty and decentralization in relation to managerial performance, but it is necessary to add other variables and are expected to be able to use a broader range of research objects. In addition, in the further study, it is hoped that the existing analytical model can be developed to get deeper results.

Conflict of interest statement and funding sources

The authors declared that they have no competing interest. The study was financed by personal funding.

Statement of authorship

The authors have a responsibility for the conception and design of the study. The authors have approved the final article.

Acknowledgments

The authors would like to acknowledge the editor of IRJMIS for their support, valuable time, and advice in completing the present article.

Kesumawati, N. K. A., Putri, I. M. A. D., \& Dwirandra, A. (2019). The role of business strategies, environmental uncertainty and decentralization as moderating the effect of management accounting systems on managerial performance. International Research Journal of Management, IT and Social Sciences, 6(3), 37-45. https://doi.org/10.21744/irjmis.v6n3.627 


\section{References}

Chenhall, R. H., \& Morris, D. (1986). The impact of structure, environment, and interdependence on the perceived usefulness of management accounting systems. Accounting Review, 16-35.

Chia, R. (1994). The concept of decision: A deconstructive analysis. Journal of management studies, 31(6), $781-806$. https://doi.org/10.1111/j.1467-6486.1994.tb00639.x

Dewi, I. G. A. A. O., Dewi, I. G. A. A. P., Kustina, K. T., \& Prena, G. D. (2018). Culture of tri hita karana on ease of use perception and use of accounting information system. International Journal of Social Sciences and Humanities, 2(2), 77-86. https://doi.org/10.29332/ijssh.v2n2.131

Erna, S., \& Tituk Dwi, S. (2006). Pengaruh Desentralisasi, Karakteristik Informasi Sistem Akuntansi Manajemen Dan Ketidakpastian Lingkungan Terhadap Kinerja Manajerial Pada PT. Alim Surya Steel. Jurnal Ilmu-Ilmu Ekonomi Vol, 6(2), 109-116.

Faisal, F., \& Prabowo, T. J. W. (2006). Pengaruh Intensitas Persaingan Pasar, Strategi Dan Ketidakpastian Lingkungan Yang Dirasakan Terhadap Penggunaan Informasi Sistem Akuntansi Manajemen Dan Kinerja Unit Bisnis. Jurnal Fakultas Hukum UII, 10(1).

Ghozali, I. (2006). Aplikasi analisis multivariate dengan program SPSS. Badan Penerbit Universitas Diponegoro.

Gordon, L. A., \& Narayanan, V. K. (1984). Management accounting systems, perceived environmental uncertainty and organization structure: an empirical investigation. Accounting, organizations and society, 9(1), 33-47. https://doi.org/10.1016/0361-3682(84)90028-X

Ingkiriwang, O. F. (2013). Pengaruh Desentralisasi dan Sistem Akuntansi Manajemen Terhadap Kinerja Manajer Dealar Di Manado. Jurnal EMBA: Jurnal Riset Ekonomi, Manajemen, Bisnis dan Akuntansi, 1(3).

Kartikawati, S. (2005). Interaksi strategi bisnis dan ketidakpastian lingkungan (perceived environmental uncertainty) terhadap hubungan antara empat karakteristik sistem informasi manajemen dan kinerja organisasi(Doctoral dissertation, Fakultas Ekonomi dan Bisnis Unika Soegijapranata).

Meiranto, W., Widiastuti, K., \& Puspitasari, E. (2014). Peran Karakteristik Sistem Akuntansi Manajemen sebagai Variabel yang Memediasi Pengaruh Teknologi Informasi dan Saling Ketergantungan Terhadap Kinerja Manajerial (Studi pada PD BPR BKK Se-Jawa Tengah).

Miles, R. E., Snow, C. C., Meyer, A. D., \& Coleman Jr, H. J. (1978). Organizational strategy, structure, and process. Academy of management review, 3(3), 546-562. https://doi.org/10.5465/amr.1978.4305755

Mulya, S. (2013). Peran penting akuntansi manajmen di perusahaan jasa. Available from: URL: http://muliasulis13.blogspot.com/2013

Nopalia, P. W. E., \& Fitriani, D. (2012). Pengaruh Penggunaan Informasi Akuntansi Manajemen dan Kepribadian Wirausaha Terhadap Kinerja Manajerial (Survei Pada Dealer Sepeda Motor di Kota Jambi). Jurnal Akuntansi Fakultas Ekonomi Universitas Jambi, 1(1), 42-49.

Rosananda, F. L. (2014). Analisis Faktor-Faktor Yang Mempengaruhi Kinerja Sistem Informasi Akuntansi Terhadap Efektivitas Pelaksanaan Sistem Pengendalian Internal. Jurnal Akuntansi Unesa, 2(2).

Rustiana, E. R. (2013). Upaya Peningkatan Kecerdasan Emosi Siswa Sekolah Dasar melalui Pendidikan Jasmani Harmoni. Jurnal Cakrawala Pendidikan, 5(1).

Sigilipu, S. (2013). Pengaruh Penerapan Informasi Akuntansi Manajemen dan Sistem Pengukuran Kinerja terhadap Kinerja Manajerial. Jurnal EMBA: Jurnal Riset Ekonomi, Manajemen, Bisnis dan Akuntansi, 1(3).

Solechan, A., \& Setiawati, I. (2009). Pengaruh Karakteristik Sistem Akuntansi Manajemen dan Desentralisasi sebagai Variabel Moderating terhadap Kinerja Manajerial (Studi Empiris Perusahaan Manufaktur di Kabupaten Semarang). Fokus Ekonomi: Jurnal Ilmiah Ekonomi, 4(1).

Sugiyono, 2009. Metode Penelitian Bisnis Cetakan lima. Bandung: Penerbit CV Alvabeta.

Supriyono, R. A. (2001). Akuntansi Manajemen. Konsep Dasar Akuntansi Manajemen dan Proses Perencanaan, Edisi Pertama BPFE, Yogyakarta.

Swastika, M. (2012). Pengertian Travel Agent.Available from: URL: http://swastikamade.blog-post.html

Yuristisia, Citra. 2011. Pengaruh Sistem Akuntansi Manajemen terhadap Kinerja Manajerial dengan Variabel Moderasi Strategi Bisnis, Perceived Environmental Uncertainty (PEU), dan Desentralisasi. Jurnal Riset Akuntansi Indonesia, 1(2), 141-160 


\section{Biography of Authors}

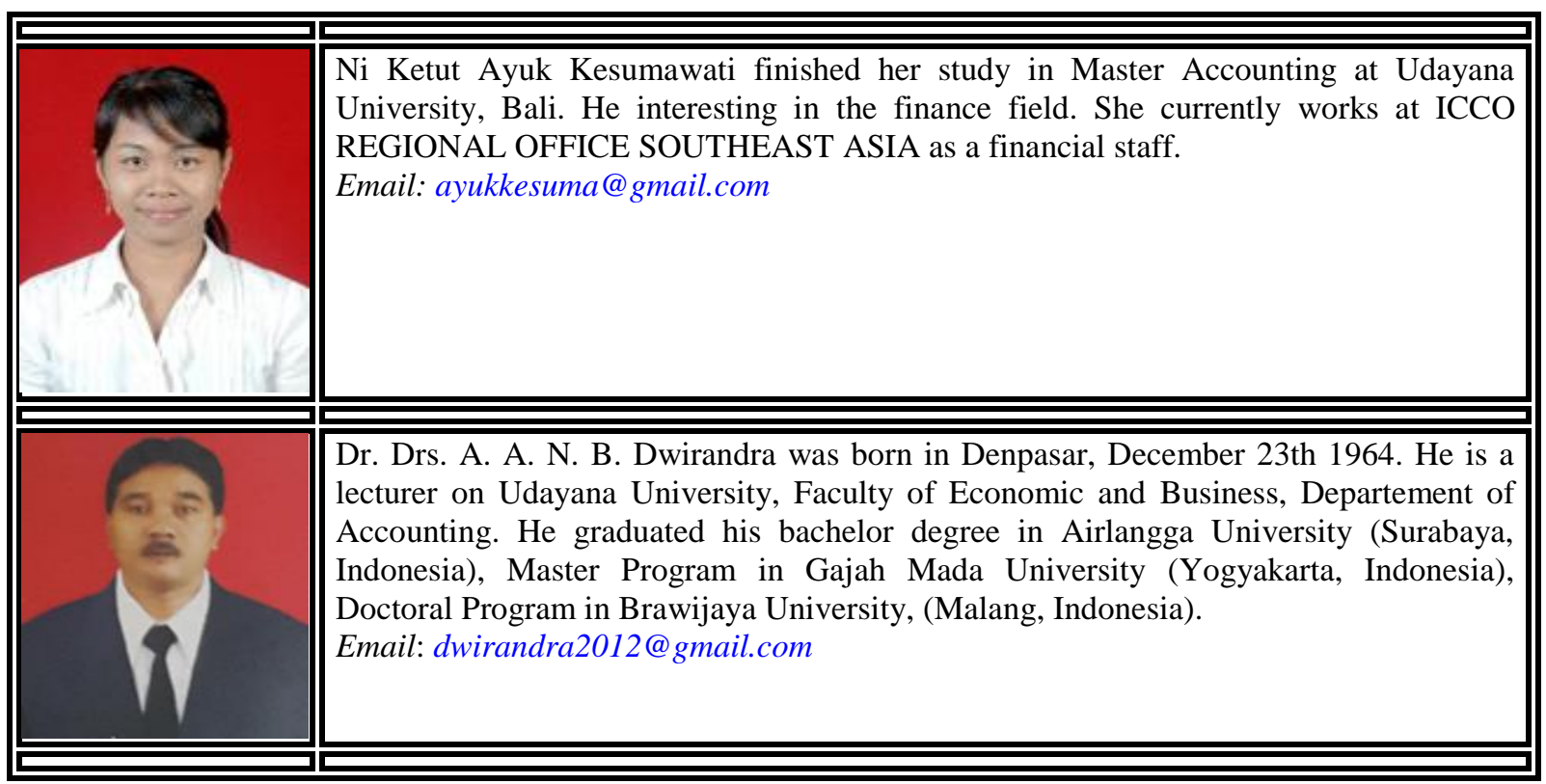

Kesumawati, N. K. A., Putri, I. M. A. D., \& Dwirandra, A. (2019). The role of business strategies, environmental uncertainty and decentralization as moderating the effect of management accounting systems on managerial performance. International Research Journal of Management, IT and Social Sciences, 6(3), 37-45. https://doi.org/10.21744/irjmis.v6n3.627 